\title{
Can Fucoidan Decrease the Mortalities Caused by Columnaris Disease in Nile Tilapia?
}

\author{
Hebatallah Ahmed Mahgoub” \\ Pathology Department, Faculty of Veterinary Medicine, Mansoura University, Egypt \\ *Corresponding author: hebamahgoub@mans.edu.eg, heba.a.mahgoub@gmail.com
}

\begin{abstract}
Columnaris disease is a serious disease in warm water fish. It is caused by Flavobacterium columnare, a Gram-negative bacterium. In this work, fucoidan was tested for its efficacy in decreasing the mortalities caused by Columnaris disease in Nile tilapia. Consequently, naturally-infected Nile tilapia with Flavobacterium columnare, showing eroded fins, rigid body figure, and ulcerated body surface, was treated with fucoidan ( $8 \mathrm{gm} / \mathrm{kg}$ ration) for 17 days. Flavobacterium columnare infection was confirmed by isolation on selective medium (cytophaga agar), from the skeletal muscle, tails fins, and gills, giving the typical rhizoid shape. It was also confirmed by Flavobacterium columnare specific PCR using selective primers for Flavobacterium columnare 16S ribosomal DNA. Fucoidan caused decreased the mortalities to nil and cured the eroded fins, the ulcerated body surface, and the rigid body figure. Fucoidan also decreased the tissue damage score to reach the normal histological score.
\end{abstract}

Keywords: columnaris disease, flavobacterium columnare, nile tilapia, fucoidan

Cite This Article: Hebatallah Ahmed Mahgoub, "Can Fucoidan Decrease the Mortalities Caused by Columnaris Disease in Nile Tilapia?" World Journal of Agricultural Research, vol. 6, no. 1 (2018): 1-4. doi: 10.12691/wjar-6-1-1.

\section{Introduction}

Fucoidan, is a branched sulphated fucan extracted from brown seaweeds and marine plants, e.g. tangleweed (Lami-naria japonica), wakame (Undaria pinnati da Sporophyll) and limu moui (Cladosiphon okamuranus) [1]. Fucoidan is known for its anti-bacterial, anti-viral, immunostimulatory, and healing stimulating effects [2-11].

Columnaris disease is caused by Flavobacterium columnare, a Gram-negative bacterium. It was first reported in 1922 and is one of the most frequently occurring diseases in freshwater fish [12]. Common names for Columnaris disease are fin rot, saddleback disease, cottonwool disease, and cotton mouth disease. The disease commonly causes serious cutaneous and gill lestions [12,13,14].

In this study, Flavobacterium columnare infected Nile tilapia was treated with fucoidan to test its efficacy on decreasing the escalating mortalities and the evolved cutaneous lesions caused by infection.

\section{Material and Methods}

\subsection{Fish}

Nile tilapia, 40-60 gm body weight, was obtained from a private fish farm at Aldakahleya Governorate, Egypt. They were maintained in aquarium tanks, provided with adequate aeration. Fifty percent of the water was exchanged twice weekly to maintain water quality. The fish were fed twice daily with a commercial diet, $3 \%$ of the body weight The water temperature was maintained at $25^{\circ} \mathrm{C} \pm 2$ during the rearing period. The experiment was conducted under 'Guide for the Care and Use of Laboratory Animals' approved by the Ethics Committee of the Faculty of Veterinary Medicine, Mansoura University.

\subsection{Experimental Design}

Nile tilapia fish was maintained in the laboratory aquaria, as a regular procedure for accomplishment of research work. Twenty fish were kept per aquarium. Signs of fin erosions and surface ulcerations appeared on all reared fish in the aquarium, together with gradual incidence of mortalities. Four dead fish were necropsied for gross examination and sample collection, for microbial isolation (from the skeletal muscle, tail fins, and gills) and histopathological examination of the skeletal muscle. The remaining fish was fed a commercial diet containing fucoidan $(8 \mathrm{gm} / \mathrm{kg}$ diet $)$ for a period of 17 days and was monitored for mortalities and persistence of surface lesions. Seventeen days post fucoidan treatment, samples were collected from treated fish and negative control normal fish (fish that received normal diet).

\subsection{Light Microscopy}

Collected skeletal muscle samples were preserved in $20 \%$ formaldehyde. Samples were processed for haematoxylin and eosin at Histology laboratory, Faculty of Medicine, Mansoura University [15]. Slides were examined using Apex biological microscope, and images 
were taken using Apex biological microscope and the Apex Minigrab.

\subsection{Micobial Isolation}

Microbial isolation was performed from collected grossly altered surface musculature, tail fins, and gills.

\subsubsection{Tissue Preparation}

Skeletal muscle, tail fins, and gills were collected with sterile tools and smashed aseptically using sterile phosphate buffered saline (PBS, $\mathrm{pH}$ 7.4), until a homogenate was obtained.

\subsubsection{Inoculation of Selective Medium}

Mile and Misra method was adopted for inoculation of the smashed tissue homogenate on bacterial agar [16]. Briefly, the homogenate was serially diluted in PBS, and $20 \mu \mathrm{l}$ of each dilution was streaked, using the standard methods, on cytophaga agar plate (tryptone $0.05 \%$ weight per volume $(\mathrm{w} / \mathrm{v})$, yeast extract $0.05 \% \mathrm{w} / \mathrm{v}$, sodium acetate $0.02 \% \mathrm{w} / \mathrm{v}$, beef extract $0.02 \% \mathrm{w} / \mathrm{v}$, and agar $0.9 \% \mathrm{w} / \mathrm{v}$ [17]. Plates were incubated at $28^{\circ} \mathrm{C}$ for 24 hours and monitored for bacterial growth.

\subsection{Polymerase Chain Reaction (PCR) Confirmation of the Isolated Bacterium}

A streak of the bacterial growth was suspeneded in Cytophaga broth and incubated at $28^{\circ} \mathrm{C}$ for 24 hours. A volume of $50 \mu \mathrm{l}$ of the resulting bacterial growth was suspended in $100 \mu \mathrm{l}$ (Tris-EDTA) TE buffer, and boiled for $5 \mathrm{~min}$. five $\mu \mathrm{l}$ were used in PCR reaction using Flavobacterium columnare $16 \mathrm{~S}$ ribosomal DNA specific primers with a resulting 250 bp product [12], Flavobacterium columnare forward primer: CGATGGGTAGGGGTCCTG AG (metabion, Germany) and Flavobacterium columnare reverse primer: GCTGCTGGCACGGAGTTAGC (metabion, Germany). Basically, the $20 \mu \mathrm{l}$ PCR reaction consisted of $10 \mu \mathrm{l}$ p PCR mastermix (iNtTRON Biotechnology, Korea), $1 \mu \mathrm{l}(10 \mathrm{pmol})$ of each primer (forward or reverse), $2 \mu \mathrm{l}$ of sample DNA and up to $20 \mu \mathrm{l}$ nuclease-free water. The thermal cycling included 1 cycle of $12 \mathrm{~min}$ at $94^{\circ} \mathrm{C}, 40$ cycles of $30 \mathrm{sec}$ at $94^{\circ} \mathrm{C}, 60 \mathrm{sec}$ at $60^{\circ} \mathrm{C}, 60 \mathrm{sec}$ at $72^{\circ} \mathrm{C}$, followed by 1 cycle of $7 \mathrm{~min}$ at $72^{\circ} \mathrm{C}$. PCR products were resolved by electrophoresis using $2 \%$ agarose gel (in Tris-Acetate-EDTA (TAE) buffer, Bioshop, Canada). The gel was placed in an electrophoresis tank containing $0.5 \%$ TAE and run for $1 \mathrm{~h}$ at $80 \mathrm{~V}$. A marker $(50 \mathrm{bp}$ ladder, iNtTRON Biotechnology, Korea) was electrophoresed beside the DNA samples to measure the size of the DNA fragments. The DNA fragments were then visualised on a UV transilluminator using long wavelength ultraviolet light.

\subsection{Tissue Damage Scoring}

A tissue damage score was used to evaluate the efficacy of fucoidan treatment as an antibacterial agent and healing stimulator against muscular damage induced by Flavobacterium columnare in Nile tilapia, using a scoring system established in this study, depending on what was previously established [18], and described in details for the examined organ (skeletal muscle) in Table 1.
Table 1. Histopathologic scoring system of the skeletal muscles.

\begin{tabular}{|c|l|}
\hline Score & Percentage of field affected \\
\hline 0 & $0 \%$ No damage was recorded \\
\hline 1 & $\begin{array}{l}\text { Up to } 25 \% \text { of degeneration and/or necrosis + leukocytic } \\
\text { infiltration }+/ \text { - haemorrhage and oedema }\end{array}$ \\
\hline 2 & $\begin{array}{l}25-50 \% \text { of degeneration and/or necrosis + leukocytic } \\
\text { infiltration }+/ \text { - haemorrhage and oedema }\end{array}$ \\
\hline 3 & $\begin{array}{l}50-75 \% \text { of degeneration and/or necrosis + leukocytic } \\
\text { infiltration }+/ \text { - haemorrhage and oedema }\end{array}$ \\
\hline 4 & $\begin{array}{l}75-100 \% \text { of degeneration and/or necrosis + leukocytic } \\
\text { infiltration }+/ \text { - haemorrhage and oedema }\end{array}$ \\
\hline
\end{tabular}

\subsection{Statistical Analysis}

Statistical analysis of tissue damage scoring data was performed using one-way analysis of variance (ANOVA), followed by Tukey's multiple comparison test for pairwise comparison, comparing each experimental group to the control one and to every other group in the experimental model, using Graphpad prism software.

\section{Results}

\subsection{Microbial Isolation and Confirmation of Flavobacterium columnare}

Following $24 \mathrm{~h}$ of incubation on the selective medium (cytophaga agar), isolation of Flavobacterium columnare was confirmed by its microbial growth on the selective medium, where colonies on were flat, rhizoid, strongly adherent, and spread across solid media surfaces forming irregular margins Figure 1.
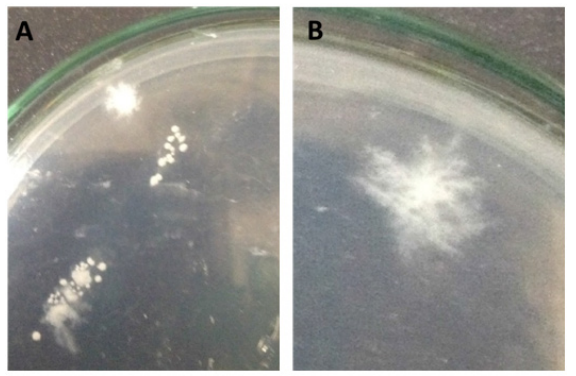

Figure 1. Isolation of Flavobacterium columnare on selective medium (cytophaga agar). A) Colonies on cytophaga agar are flat, rhizoid, strongly adherent, and spread across solid media surfaces forming irregular margins. B) A higher magnification of one of Flavobacterium columnare rhizoid colonies

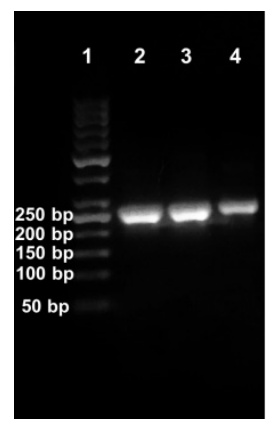

Figure 2. PCR amplification products of Flavobacterium columnare $16 \mathrm{~S}$ ribosomal DNA using Flavobacterium columnare specific primers. Amplification products ( $250 \mathrm{bp})$ were resolved through a $2 \%$ agarose gel. Lane 1: 50 bp ladder (iNtTRON). Lane 2: Flavobacterium columnare isolated from the muscle. Lane 3: Flavobacterium columnare isolated from the tail fin. Lane 4: Flavobacterium columnare isolated from the gills 
Furthermore, Flavobacterium columnare detection was confirmed by PCR (in the muscle, tail fins, and gills) using Flavobacterium columnare $16 \mathrm{~S}$ ribosomal DNA specific primers (Figure 2).

\subsection{Gross Examination of Infected and Infected Treated Nile Tilapia}

Flavobacterium columnare natural infection of Nile tilapia caused fin erosions and surface ulcerations, together with gradual incidence of mortalities (Figure 3). Fucoidan treatment decreased the mortalities to naught and cured the eroded fins, the ulcerated body surface, and the rigid body figure (Figure 3 ).
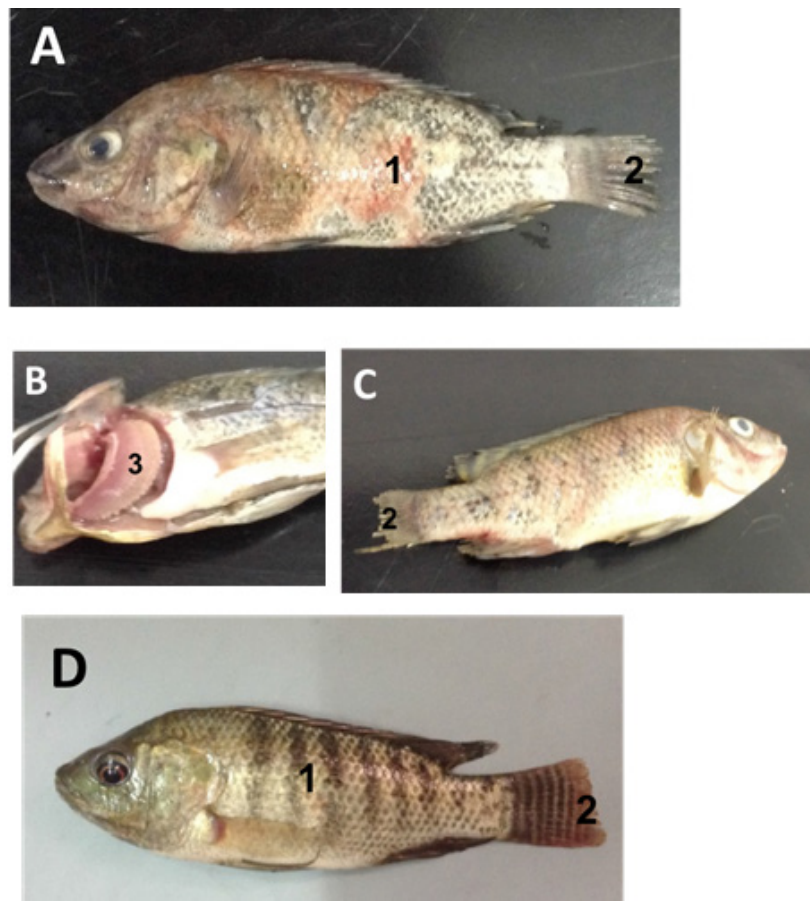

Figure 3. Gross examination of Nile tilapia infected with Columnaris disease, pre- and post-treatment with fucoidan. A) An infected fish showing an ulcerated and haemorrhagic external surface (1) and eroded tai-fin (2). B) An infected fish showing pale gills (3). C) An infected fish showing body stiffness/rigidity and eroded tai-fin (2). D) An infected treated fish showing normal external surface, body figure/elasticity, and fins

\subsection{Histopathological examination and tissue damage scoring of the musculature}

Flavobacterium columnare infected muscles showed partial or complete myomalacia, muscular hyaline degeneration, intermuscular oedema, intermuscular leukocytic infiltration, and haemorrhage (Figure 4).

Using the established tissue damage scoring (Table 1), fucoidan treatment of infected Nile tilapia with Columnaris disease cause complete healing of altered musculature (Figure 5).

\section{Discussion}

In this study, Flavobacterium columnare infected Nile tilapia was treated with fucoidan to test its efficacy on decreasing the escalating mortality rate and the evolved lesions caused by infection. Therefore, naturally-infected Nile tilapia with Flavobacterium columnare was treated with fucoidan ( $8 \mathrm{gm} / \mathrm{kg}$ ration) for 17 days and tested for its effect on decreasing the mortality rate and surface lesions caused by the infection.
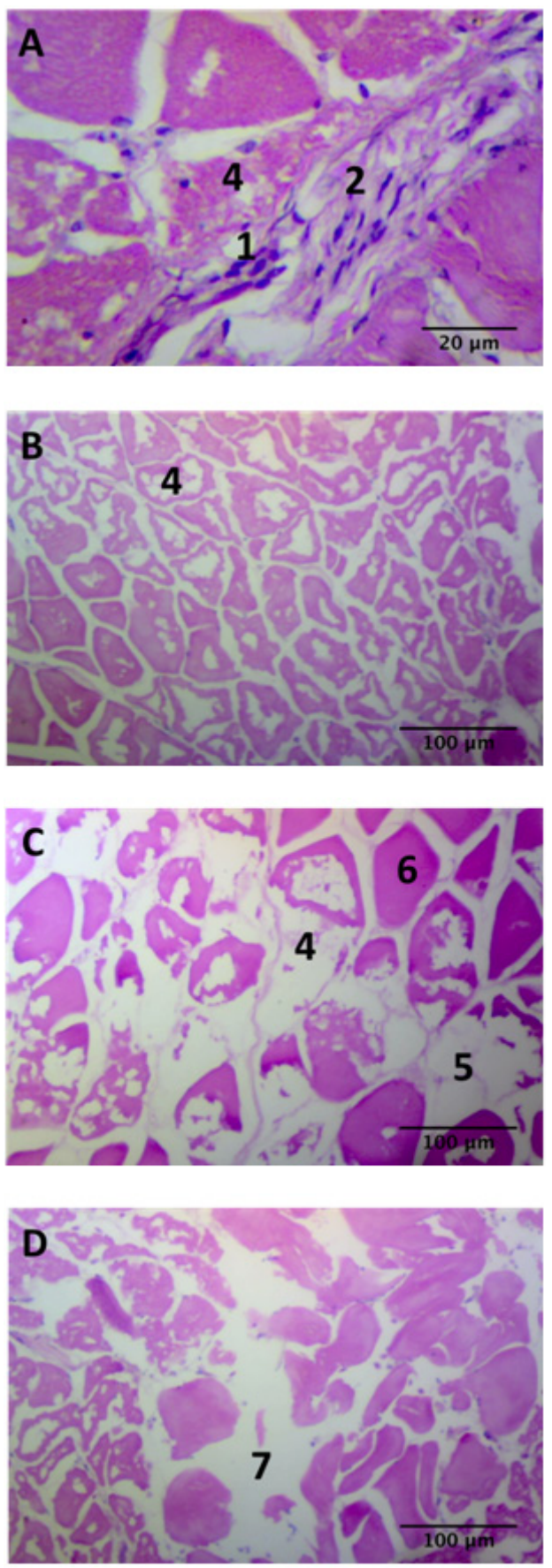

$1=$ inflammatory cells

2- fibroblast proliferation

$3=$ erythrocytes

$4=$ partial muscle degradation or myomalacia

$5=$ complete muscular degradation or myomalacia

$6=$ Hyaline degeneration of the myocyte.

$7=$ oedema.

Figure 4. Miscroscopical alterations caused by Columnaris disease infection in Nile tilapia. A) The micrograph shows marked intermuscular leukocytic infiltration, fibroblast proliferation, and extravasation of erythrocytes. B) The micrograph shows partial muscle degradation or myomalacia. C) The micrograph shows partial and complete muscle degradation or myomalacia. D) The micrograph shows intermuscular oedema 
Columnaris disease commonly causes serious cutaneous and gill lestions [12,13,14]. Flavobacterium columnare natural infection (in the muscles, tail fins, and gills of Nile tilapia) was confirmed by its isolation on selective medium (cytophaga agar), giving the typical rhizoid shape. It was also confirmed by Flavobacterium columnare specific PCR using selective primers for Flavobacterium columnare $16 \mathrm{~S}$ ribosomal DNA [12].

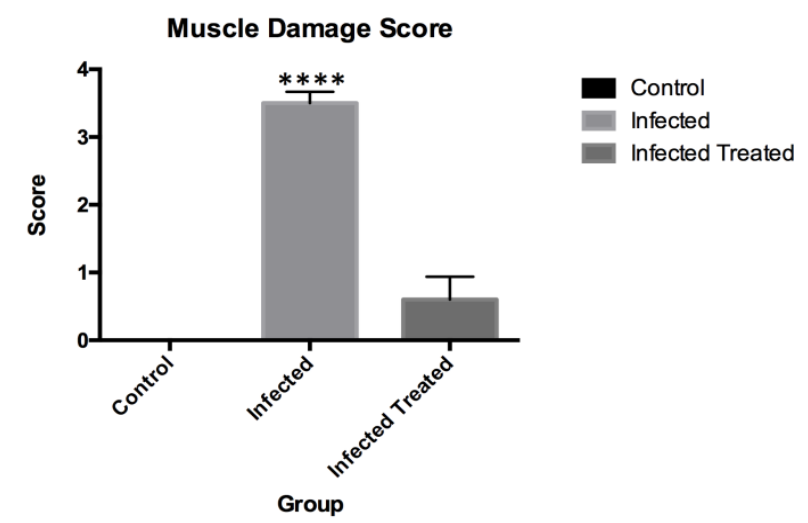

Figure 5. Tissue damage score of the surface muscle in different experimental groups. Score data were analysed using one-way ANOVA, followed by Tukey's multiple comparison test, where each group was compared to the control group and every other group. $* * * *$ means $\mathrm{p}$ value $<0.0001$

Fucoidan treatment decreased the mortalities to $0 \%$ and cured the eroded fins, the ulcerated body surface, and the rigid body figure. Fucoidan also decreased the tissue damage score to reach the normal histological score. Therefore, this study demonstrated apparent anti-bacterial and cutaneous wound healing effects of fucoidan. Fucoidan is known for its anti-bacterial, anti-viral, immunostimulatory, and healing stimulating effects [2-11]. In a previous study, fucoidan inhibited the growth of Staphylococcus aureus and Escherichia coli [5]. Fucoidan was also used as a prevention and treatment measure to control diseases caused by Helicobacter pylori [4]. Similutaneously, previous liteature demonstrated the cutaneous wound healing effect of fucoidan $[10,11]$.

\section{Conclusion}

In a natural model of Columnaris disease in Nile tilapia, fucoidan treatment could decrease the resulting mortalities from infection and improved the apparent cutaneous and fins health and general body figure elasticity.

\section{Conflict of Interest}

The author declares no conflict of interest.

\section{Acknowledgements}

This research did not receive any specific grant from funding agencies in the public, commercial, or not-forprofit sectors.

\section{References}

[1] Seok, J., Kim, T.S., Kwon, H.J., Lee, S.P., Kang, M.H., Kim, B.J., et al. Efficacy of Cistanche Tubulosa and Laminaria Japonica Extracts (MK-R7) Supplement in Preventing Patterned Hair Loss and Promoting Scalp Health. Clin Nutr Res 2015; 4(2): 124-31.

[2] Trejo-Avila, L.M., Morales-Martinez, M.E., Ricque-Marie, D., Cruz-Suarez, L.E., Zapata-Benavides, P., Moran-Santibanez, K., et al. In vitro anti-canine distemper virus activity of fucoidan extracted from the brown alga Cladosiphon okamuranus. Virusdisease 2014; 25(4): 474-80.

[3] Pomin, V.H. Sulfated glycans in inflammation. Eur J Med Chem 2015; 92: 353-69.

[4] Besednova, N.N., Zaporozhets, T.S., Somova, L.M., Kuznetsova, T.A. Review: prospects for the use of extracts and polysaccharides from marine algae to prevent and treat the diseases caused by Helicobacter pylori. Helicobacter 2015; 20(2):89-97.

[5] Yu, S.H., Wu, S.J., Wu, J.Y., Wen, D.Y., Mi, F.L. Preparation of fucoidan-shelled and genipin-crosslinked chitosan beads for antibacterial application. Carbohydr Polym 2015; 126:97-107.

[6] Aguilar-Briseno, J.A., Cruz-Suarez, L.E., Sassi, J.F., RicqueMarie, D., Zapata-Benavides, P., Mendoza-Gamboa, E., et al. Sulphated polysaccharides from Ulva clathrata and Cladosiphon okamuranus seaweeds both inhibit viral attachment/entry and cellcell fusion, in NDV infection. Mar Drugs 2015; 13(2):697-712.

[7] Abuajah, C.I., Ogbonna, A.C., Osuji, C.M. Functional components and medicinal properties of food: a review. J Food Sci Technol 2015; 52(5): 2522-9.

[8] Zhang, W., Oda, T., Yu, Q., Jin, J.O. Fucoidan from Macrocystis pyrifera has powerful immune-modulatory effects compared to three other fucoidans. Mar Drugs 2015; 13(3):1084-104.

[9] Purnama, A., Aid-Launais, R., Haddad, O., Maire, M., Mantovani, D., Letourneur, D., et al. Fucoidan in a 3D scaffold interacts with vascular endothelial growth factor and promotes neovascularization in mice. Drug Deliv Transl Res 2015; 5(2): 187-97.

[10] Park, J.H., Choi, S.H., Park, S.J., Lee, Y.J., Park, J.H., Song, P.H., et al. Promoting Wound Healing Using Low Molecular Weight Fucoidan in a Full-Thickness Dermal Excision Rat Model. Mar Drugs $2017 ; 15(4)$.

[11] Sezer, A.D., Cevher, E., Hatipoglu, F., Ogurtan, Z., Bas, A.L., Akbuga, J. Preparation of fucoidan-chitosan hydrogel and its application as burn healing accelerator on rabbits. Biol Pharm Bull 2008; 31(12): 2326-33.

[12] Tripathi, N.K., Latimer, K.S., Gregory, C.R., Ritchie, B.W., Wooley, R.E., Walker, R.L. Development and evaluation of an experimental model of cutaneous columnaris disease in koi Cyprinus carpio. J Vet Diagn Invest 2005; 17(1):45-54.

[13] Amin, N.E., Abdallah, I.S., Faisal, M., Easa, M.e.-S., Alaway, T., Alyan, S.A. Columnaris infection among cultured Nile tilapia Oreochromis niloticus. Antonie Van Leeuwenhoek 1988; 54(6): 509-20.

[14] Kubilay, A., Altun, S., Diler, O., Ekici, S. Isolation of Flavobacterium columnare from Cultured Rainbow Trout (Oncorhynchus mykiss) Fry in Turkey. Turkish Journal of Fisheries and Aquatic Sciences 2008; 8:165-9.

[15] Bancroft, J.D., Gamble, M. Theory and practice of histological techniques. 6th ed. ed. [Edinburgh]: Churchill Livingstone, 2008.

[16] Miles, A.A., Misra, S.S., Irwin, J.O. The estimation of the bactericidal power of the blood. J Hyg (Lond) 1938; 38(6):732-49.

[17] Farmer, B. IMPROVED METHODS FOR THE ISOLATION AND CHARACTERIZATION OF FLAVOBACTERIUM COLUMNARE: Graduate Faculty of the Louisiana State University and Agricultural and Mechanical College; 2004.

[18] Klopfleisch, R. Multiparametric and semiquantitative scoring systems for the evaluation of mouse model histopathology--a systematic review. BMC veterinary research 2013; 9:123. 